\title{
Design of the detecting platform for the electronic control rotary dobby DOI: 10.35530/IT.072.03.1751
}

\author{
HONGHUAN YIN
}

HONGBIN YU

\author{
JUNQIANG PENG
}

HONGYU SHAO

\author{
ABSTRACT - REZUMAT \\ Design of the detecting platform for the electronic control rotary dobby
}

In order to meet the factory detection requirements of the rotary electronic dobby, a new design of the detecting platform for the rotary electronic dobby was proposed in the present study. It was composed with three main modules to meet the different levels of detecting process all over the factory, including the embedded control system, human machine interface system and the information management system. For the information management system of the dobby workshop, the proposed platform performed the remote management, results monitor, and data analysis to the dobby manufactured at the factory. For the operators of the dobby detecting process, the human machine interface system realized the edit of pattern, the upload and download of the pattern data based through Wi-Fi, the control of motor speed, the test process record and the upload of the test results. Moreover, the embedded control system was developed and built to realize the real-time control to electromagnet and swing arms of dobby according to the pattern stored in flash chip and status display of the detecting results on the platform. The designed detecting platform in this article can be widely applied in the factory for detection of the rotary electronic dobby. The reliability and practicability of the proposed platform have been confirmed by the practical application of the dobby manufacturing enterprise.

Keywords: detecting platform, dobby control, information management, pattern design, rotary electronic dobby

\section{Proiectarea platformei de detectare pentru comanda electronică a ratierei rotative}

Pentru a îndeplini cerințele de detecție din producție ale ratierei rotative electronice, în prezentul studiu a fost propus un nou design al platformei de detectare pentru ratiera rotativă electronică. Acesta se compune din trei module principale pentru a îndeplini diferitele niveluri ale procesului de detectare în întreaga fabrică, inclusiv sistemul de control încorporat, sistemul de interfață om-mașină și sistemul de gestionare a informațiilor. Pentru sistemul de gestionare a informațiilor din secția cu ratieră, platforma propusă a efectuat gestionarea la distanță, monitorizarea rezultatelor și analiza datelor către ratiera. Pentru operatorii procesului de detectare a ratierei, sistemul de interfață om-mașină a realizat editarea modelului, încărcarea și descărcarea datelor modelului bazate pe Wi-Fi, controlul vitezei motorului, înregistrarea procesului de testare și descărcarea rezultatelor testului. Mai mult decât atât, sistemul de control încorporat a fost dezvoltat și construit pentru a realiza controlul în timp real al electromagnetului și brațelor oscilante ale ratierei în conformitate cu modelul stocat în cip și afișarea rezultatelor detectării pe platformă. Platforma de detectare proiectată în acest articol poate fi aplicată pe scară largă în producție pentru detectarea ratierei rotative electronice. Fiabilitatea și practicabilitatea platformei propuse au fost confirmate de aplicația practică a întreprinderii producătoare de ratieră.

Cuvinte-cheie: platforma de detectare, controlul ratierei, gestionarea informațiilor, proiectarea modelelor, ratieră rotativă electronică

\section{INTRODUCTION}

Rotary electronic dobby is a type of positive dobby, which has been mainly used with rapier and projectile weaving machines. In recent years, manufacturers have demonstrated their rotary dobby at the international exhibitions. This makes it possible to employ a rotary dobby on high speed air jet and water jet weaving machines. Today, it is a dominant type of dobby in industry that can be used on all types of weaving machines [1-3].

As an important part of the weaving machinery, the rotary electronic dobby plays an important role in improving the efficiency and quality of the weaving machine. The rotary electronic dobby is an advanced opening device of looms, which plays an irreplaceable role in the research and development of new fabrics and batch weaving. Excellent output motion characteristics and advanced control technology of the rotary electronic dobby provide the necessary foundation for the development of high-speed and flexible looms. Meanwhile, the performance of the rotary electronic dobby directly affects the yield and quality of the fabric.

However, reviewing the literature indicates that few publications have been conducted so far on the control and detection of rotary electronic dobby. On the other hand, it is a great challenge to control the rotary electronic dobby produced by the manufacturer company so that the quality of the rotary electronic dobby cannot be guaranteed and the quality of the rotary electronic dobby and non-systematic operation of key operating parameters cannot be guaranteed $[4,5]$. This remarkable drawback hinders users to provide the required information for manufacturing enterprises, 
thereby seriously restricting the digital development in the textile industry.

The working condition of the rotary electronic dobby is complicated during the factory inspection process. The detecting items of the platform include electromagnet current, electromagnet temperature, electromagnet working state, running speed of dobby, working time, vibration, lubricating oil temperature, lubricating oil level motor running state, inverter running, fault signal, electromagnet current abnormal information, electromagnet execution abnormal information. It is necessary to determine whether the rotary electronic dobby can perform the relevant actions smoothly and orderly. Moreover, it is of significant importance to study the control methods and develop techniques for the rotary electronic dobby. The present article intends to present a factory detection platform for the rotary electronic dobby.

\section{STRUCTURE OF THE DETECTION PLATFORM}

In the present study, the principle of the rotary electronic dobby is combined with the loom $[6,7]$ to design and develop a rotating electronic dobby (hereafter called "dobby") detecting platform. Figure 1 illustrates the structure of the proposed detecting platform. It indicates that the platform is mainly composed of three parts, including the embedded control system (ECS), human machine interface system (HMIS) and the information management system (IMS). The ECS controls the start and stop of the frequency converter /motor, provides the electromagnet pull-off signal in accordance with the pattern information and detects the running status of the dobby. Moreover, the HMIS realizes operational parameter setting, pattern management, selection of the detection mode, and presentation of the data detection in the dobby. Finally, the IMS manages the shop-level dobby detection process.

\section{ECS OF THE DETECTING PLATFORM}

The ECS hardware circuit of the designed dobby consists of an ATmega128 microcontroller, power management module, pattern storage module, optocoupler isolation module, power drive module, Wi-Fi module and RS485 communication module. Figure 2 illustrates the ECS structure for the proposed design. Figure 2, a shows the hardware connection diagram, which presents the dobby structure, the function of the detection board, and the communication relationship with the HMIS. Furthermore, figure $2, b$ shows the basic circuit principle diagram of the proposed scheme. It indicates that the ECS consists of an ATmega128 microcontroller for power management, data communication, dobby control and detection.

\section{Communication and pattern storage}

The ECS employs two communication methods, one is RS-485 wired and the other is Wi-Fi wireless communication. The structure diagram of these methods is shown in figure 2. RS-485 communication module forms the protocol analysis between ECS and frequency converter through the MAX485 chip under the action of the control signal. Moreover, it realizes the frequency converter and the motor control. On the other hand, the Wi-Fi communication module receives the pattern data and controls commands transmitted from the HMIS to the ECS, performs controlling and detection operations of the dobby, and returns the detected data to the HMIS.

The pattern storage part employs FM24C512 flash chip. In order to meet the system requirements, the proposed design uses two FM24C512 flash chips with $1 \mathrm{MB}$ of storage space. This memory performs continuous reading and writing operations at the bus speed up to $1 \mathrm{MHz}$. It should be indicated that the $\mathrm{read} / \mathrm{write}$ operation consumes only $250 \mu \mathrm{A}$ at 100 $\mathrm{KHz}$, which is an extremely low power consumption. Moreover, application of the two-wire interface TWI $\left({ }^{2} \mathrm{C}\right)$ of the ATmega128 microcontroller is simple and convenient so that this feature is applied on the FM24C512 to meet the requirements of the ECS.

\section{Frequency converter/motor control}

The detecting platform uses Schneider frequency converter with rated power of $7.5 \mathrm{KW}$ and Schneider three-phase $\mathrm{AC}$ motor with $5 \mathrm{KW}$ to drive the rotation of the dobby main shaft. The ECS performs the bidirectional communication with the frequency converter through RS-485 serial communication and adopts the MODBUS communication protocol of the frequency converter. Moreover, it performs the start/ stop operation, forward/reverse rotation, adjusts the speed and the fault alarm of the motor, and completes the dobby motion control during the machine detection.

\section{Dobby control}

The high-speed multichannel electromagnet and swing arms

Fig. 1. Structure of the proposed detecting platform 


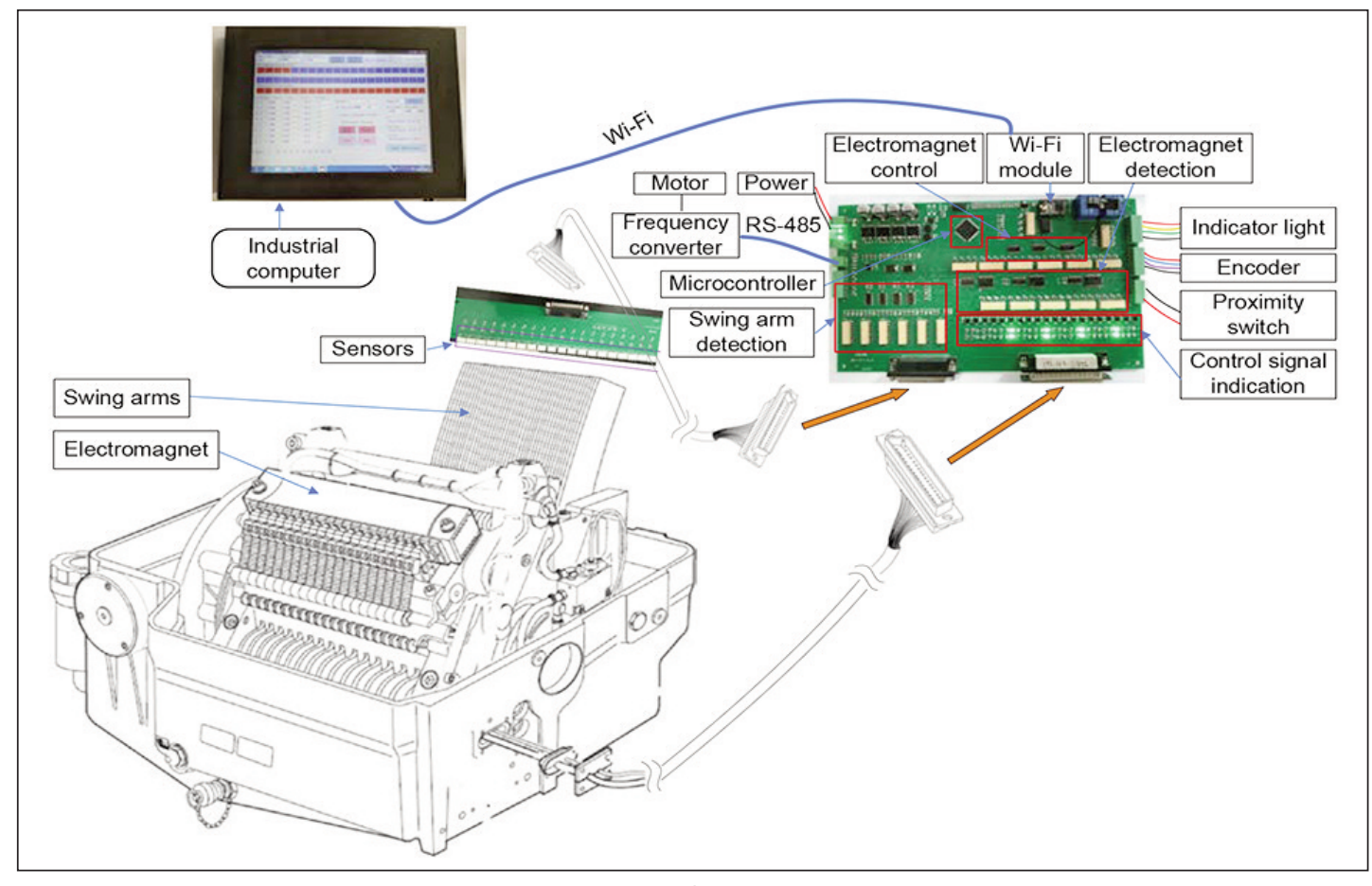

a

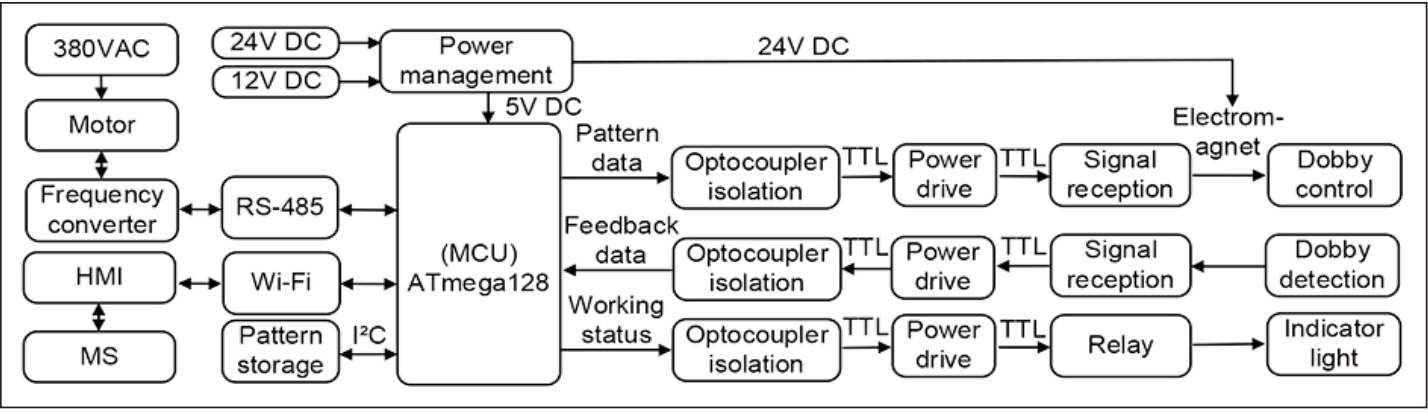

b

Fig. 2. ECS structure of the proposed scheme: $a$ - hardware connection diagram; $b$ - basic circuit principle diagram

act as the first-stage signal actuator of the dobby, which plays a vital role in the performance of the entire dobby. Therefore, it is of significant importance to control and detect the electromagnet and swing arms motion. The control items of the detecting platform include dobby operation control, pattern data storage, inverter and motor drive, electromagnet drive, electromagnet magnetic induction intensity acquisition, electromagnet current acquisition, swing arm motion state acquisition, oil temperature and liquid level information collection. Figure 3 schematically shows the control and detection module. It indicates that after reading the machine parameters of the selected pattern file, the pattern file is converted to the format required by the dobby ECS. In the process of control and detection, the electromagnet has two action modes, entitled by pull-in and release modes, which correspond to the logic "1" and logic "0" in the logic circuit, respectively. After reading the pattern file, the ECS determines whether the pattern data is " 1 " or " 0 ". When the data is " 1 ", the electromagnet energizes and it is pulled-in so that the corresponding swing arms move. Otherwise, when the data is " 0 ", the electromagnet is powered off and it is released so that the corresponding swing arms remain stationary. Therefore, as shown in figure $3, a$, a pattern drawn by the pattern file is formed on the fabric in accordance with the dobby ECS.

The electromagnet is controlled according to the control signal and the structural information. Figure $3, b$ illustrates the timing chart for the studied case. In A and $B$ areas of the weaving machine, the microprocessor combines the pattern information to control the electromagnet. The working state of the electromagnet determines the movement of the heald frame of the loom during the weaving process. The working voltage of the electromagnet is set to $24 \mathrm{~V} \mathrm{DC}$. When the voltage is applied, the electromagnet is pulled-in and the swing arms move. On the other hand, the electromagnet is disconnected when the voltage is released. At this time, the swing arms are stationary. Since the electromagnet resistance of each path is approximately 230, ULN2803 microprocessor is required for power amplification during driving the swing arms. Since the number of electromagnets is large, while the Input/Output (I/O) of the ATmega128 is limited, the $74 \mathrm{HC} 590$ device is applied as the serial 


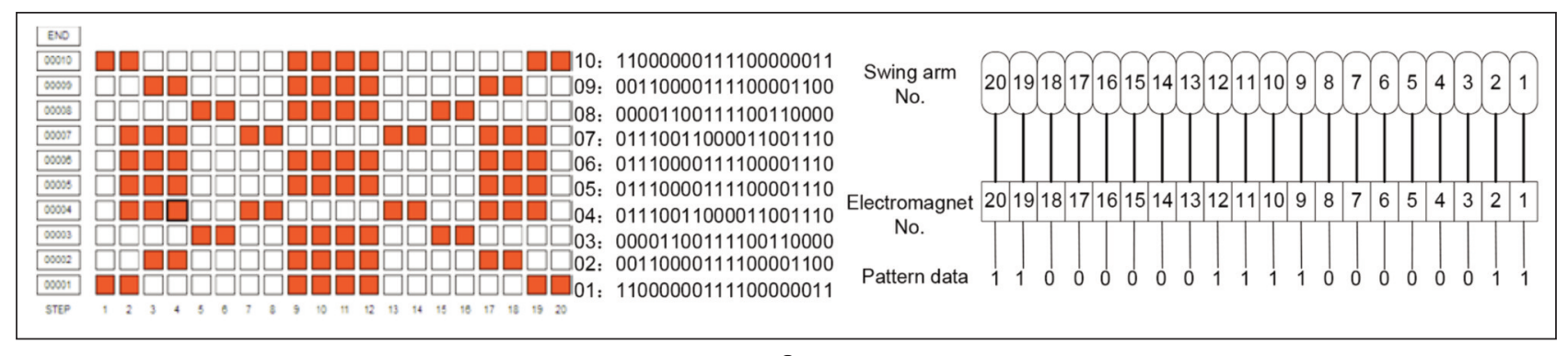

a

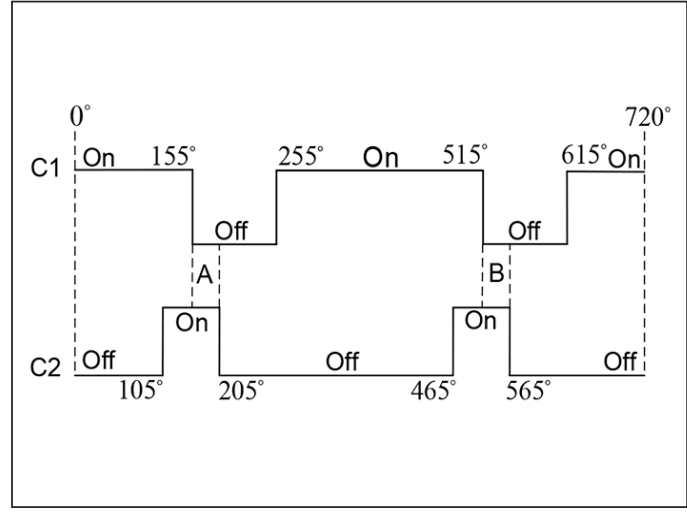

b

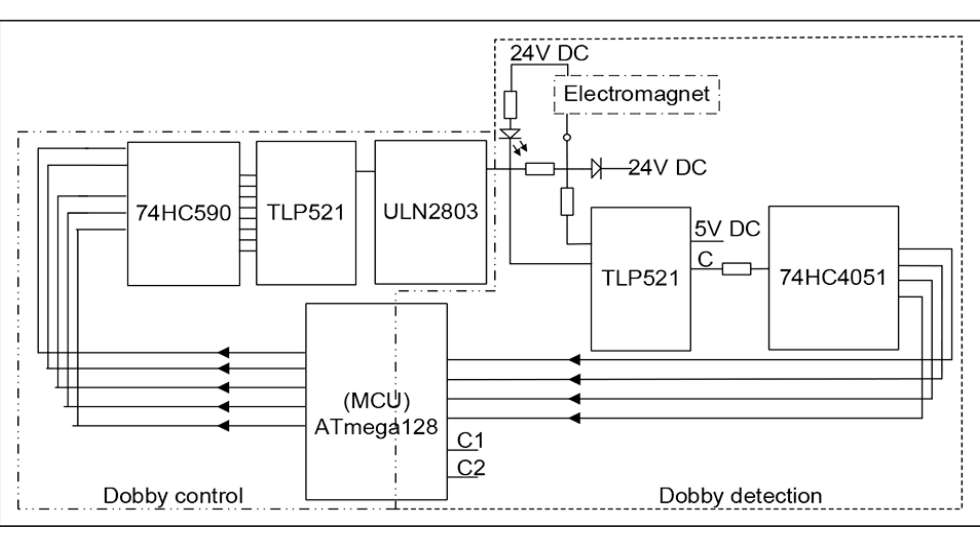

c

Fig. 3. Control and detection modules: $a$ - pattern information and control signal conversion; $b$ - timing chart of the control and detection operations; $c$ - schematic of the control and detection modules

shift output control. Figure 3,c illustrates the control and detection schematic in this regard.

The signal plate is fixed on the main shaft of the dobby [8-11], and the rotational direction of the main shaft is detected by the photoelectric switch sensors. Meanwhile, two photoelectric switches can accurately detect the forward and reverse work of the dobby machine, which originates from the special shape of the signal disc.

\section{Dobby detection}

The principle of electromagnet and swing arms state detection is shown in figure 3,c. When the electromagnet is powered, the corresponding optocoupler (TLP521) input is turned on. Then the output end of the optocoupler is turned on in accordance with its working principle and the $\mathrm{C}$ terminal of the microcontroller generates a voltage of about $5 \mathrm{~V}$, and the $\mathrm{C}$ port is connected to the $1 / O$ of the microcontroller. Based on this principle, it can be judged whether the electromagnet is attracted or not.

Similarly, photoelectric switch sensors are installed at the extreme position of the swing arms motion to detect whether the motion is consistent with the given pattern information, and determine whether the swing arms are in the correct state of motion. The obtained detection data is transmitted to the HIMS through the Wi-Fi wireless communication module.

\section{Auxiliary function}

The power management module provides Power supply with various voltages and amperes for the ECS of the entire dobby. Since the working voltage of the ECS microprocessor is inconsistent with that of the electromagnet, the electromagnet avoids the reverse impact of the controller and introduces electromagnetic interference when performing highspeed on-off operation. Moreover, the electromagnet adopts the optocoupler isolation design to effectively prevent spikes and various noise disturbances. Therefore, two power supplies are selected in the proposed design. The first one supplies $12 \mathrm{~V} \mathrm{DC}$, which is then turned into $5 \mathrm{~V} \mathrm{DC}$ to supply power for the main controller through the buck and voltage regulation. The other channel is a $24 \mathrm{~V} D C$ power supply, which is powered by the filter and then it supplies the electromagnet.

When the dobby is working normally, the indicator light is green. When the dobby fails, the indicator light turns yellow. Moreover, when the dobby is powered off, the indicator light is red. The electromagnet indicator can be flashed according to the given pattern data so that the movement status and pattern data of the electromagnet are presented. The control circuit and program utilize a watchdog timer and a punctual interrupt to monitor the running status of the program. When the program runs out of order, the watchdog timer restarts the execution of the program through an internal interrupt.

\section{HMIS OF THE DETECTING PLATFORM}

In order to design an interactive interface that can directly perform the parameter setting, pattern management and the dobby detection, the HMIS of the dobby is programmed in the Visual Studio 2012 environment. Figure 4 illustrates the provided HIMS. Pattern film selection, input parameters of process, and reading/conversion parameters of the machine are obtained through interactive dialogue boxes. It 


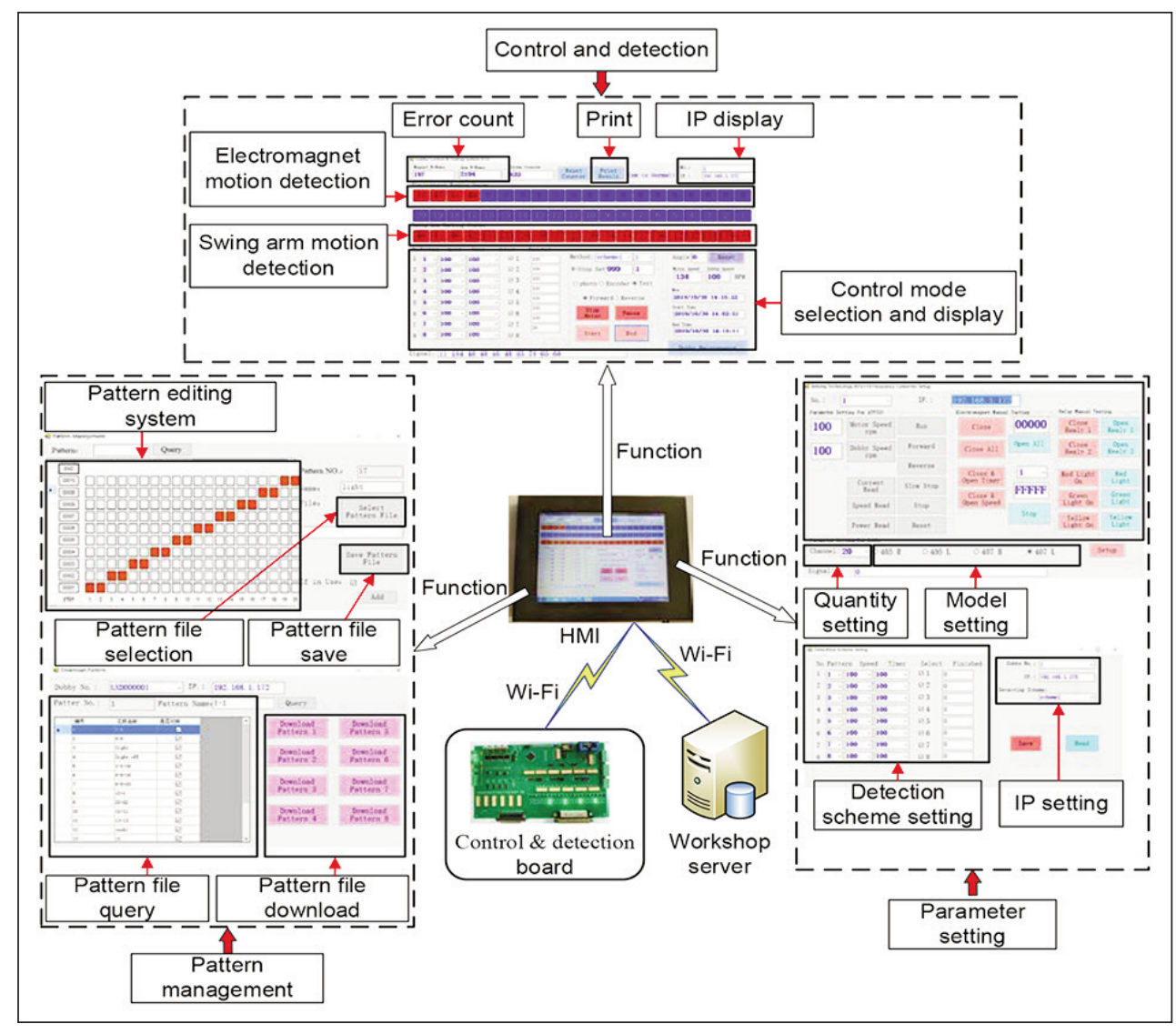

Fig. 4. HMIS structure saved, queried, downloaded, renamed and deleted. The pattern design software can be applied simply and effectively to the ECS of the dobby. In the HMIS, a function is considered for the user to call the pattern design software. The user designs the pattern in accordance with the detection process, and can store the designed pattern in the database to create a pattern library.

Since the interactive system of the dobby is installed on the industrial computer, multiple pattern information can be stored at the same time. In order to facilitate the created file management, each pattern file has a name. In the practical application, the user should

should be indicated that the HMIS of the dobby has wireless communication capabilities with a Windows operating system. Furthermore, the HMIS of the dobby can debug, evaluate the dobby performance, analyze and store data. In order to overcome the challenges of field wiring in the dobby industry, the HMIS transmits data to the dobby ECS through the wireless communication. The transmitted data include the pattern information and control commands. In order to preserve data and perform the analysis on the data, the test data is transmitted to the workshop server through the Wi-Fi protocol.

\section{Parameter setting}

In this section, the control and detection parameters of the dobby, including the number of swing arms, dobby model, swinging speed, detection scheme and IP address settings, are set. It should be indicated that the number of swing arms of the dobby is generally a multiple of 8 , such as $16,24,32$, or a multiple of 4 , such as $12,16,20,24,28$. Therefore, the number of swing arms should be initially determined. Moreover, the dobby model is different and should be set. In the detection of the dobby, it is also necessary to set a detection scheme, and when the scheme is saved, the scheme is selected in accordance with the detection process.

\section{Pattern management}

Pattern management includes the function of the pattern design software [12], pattern files can be selected, only select the file list column of the basic pattern, and select the desired pattern according to the pattern name. Then the pattern will be called from the pattern library. Each pattern file obtains the pattern required for controlling and detecting the dobby.

\section{Control and detection}

Control and detection include controlling the frequency converter/motor, dobby electromagnet and swing arms action, and checking whether the electromagnet and swing arms work normally. The control and detection modes are applied to determine the structure and model of the dobby.

When the on/off state of each electromagnet and the action state of the swing arms are the same as those of the given pattern, the action state of the electromagnet and the swing arms are detected. If they are the same, the blue color is displayed on the dobby HMIS, while if they are not the same, the HMIS displays a red color accordingly. The number of errors is recorded, and the number of downtimes with the number of errors is set. If the number of errors exceeds the set value, the detection process will automatically stop. The test report can be automatically printed when the test is completed.

\section{IMS OF THE DETECTING PLATFORM}

The IMS is applied for the factory inspection process of the dobby. The dobby manufacturing enterprise can obtain its running status and data, and realize centralized data management for all the dobby 


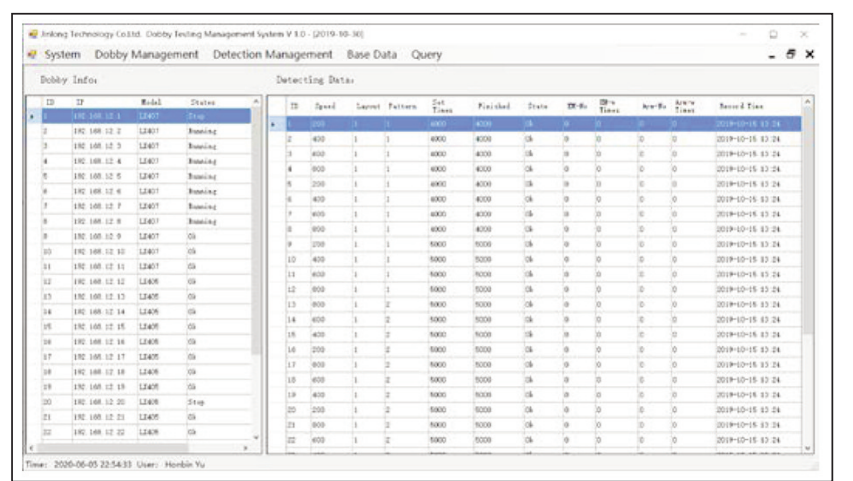

a

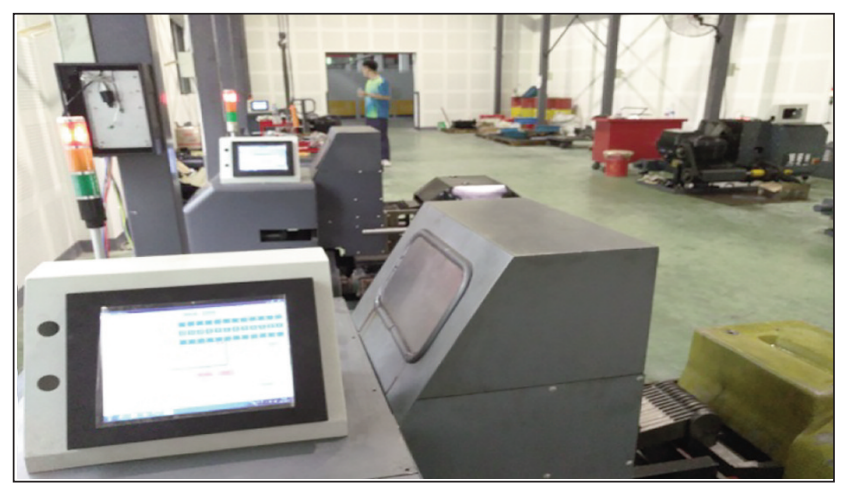

b

Fig. 5. Application of the detection platform: $a$ - IMS structure; $b$-detecting platform layout

machines detected in the factory. On the one hand, the dobby to be detected is assigned to the detection platform, where the corresponding inspection plan is arranged. On the other hand, the technician can view demanded information, including the process data, detection scheme and detection results of the dobby. Figure 5, a shows the designed IMS structure.

The IMS helps dobby manufacturers obtain the health status of the product in the real time, evaluate the performance of the dobby, continuously improve the technical optimization equipment, and improve the product quality.

\section{APPLICATION OF THE DETECTING PLATFORM}

In the factory application process, the detection platform of the dobby overcomes the reliability problem of long-term operation, and solves operational problems such as control of the dobby and factory detection. The presented detection platform in figure $5, b$ has been applied in Jiangsu Jinlong Technology Co., Ltd. It should be indicated that the detection platform has superior characteristics, including convenient operation, friendly interface and comprehensive functions. Moreover, it meets the requirements of the dobby factory detection and it can be widely promoted in diverse aspects.

\section{CONCLUSIONS}

In the present study, a dobby detection platform is designed and developed, where the platform consists of ECS, HMIS and IMS. The ECS is designed to control the frequency converter/motor, electromagnet and the swing arms. Moreover, it can detect the action state of the electromagnet and the swing arms, and satisfy the control and detection design principles. The HMIS integrates a series of functions such as call design, pattern files selection and procession. In order to improve the efficiency of the designed pattern, the pattern information can be transmitted to the embedded system through a wireless communication. The management system displays the test results of the dobby so that the dobby manufacturers can obtain the health status of the produced dobby in the real-time.

The present study shows that the proposed platform satisfies the factory inspection requirements of the dobby, improves the digitization level of the dobby detection platform, and greatly reduces the cost of the pattern control. It can be widely used in the factory inspection of the dobby to perform the factory inspection of the dobby intelligently. The reliability and usability of the proposed platform has been proven by the practical application of the dobby manufacturers.

\section{REFERENCES}

[1] Eren, R., Özkan, G., Turhan, Y., Kinematics of rotary dobby and analysis of heald frame motion in weaving process, In: Fibres \& Textiles in Eastern Europe, 2008, 78, 12, 1070-1079

[2] Adanur, S., Handbook of weaving, In: CRC Press, 2000, 110-125

[3] Marks, R., Robinson, A.T.C., Principles of weaving, In: The Textile Institute, 1976, 59-72

[4] Shen, Y., Yang, M., Deng, W.J., Research on 3620 rotary electronic dobby test based on LabVIEW, In: Advanced Textile Technology, 2015, 23, 4, 24-28

[5] Sun, H.M., Software and hardwre design and implementation of the embedded data acquisition and analysis system for equipment monitoring, In: Beijing Jiaotong University, 2014

[6] Yuan, Y.H., Matching mechanism for rotary electronic dobby and loom, In: Journal of Silk, 2000, 8, 24-26

[7] Abdulla, G., Hascelik, B., Palamutcu, S., et al., Synthesis work about driving mechanism of a novel rotary dobby mechanism, In: Tekstil ve Konfeksiyon, 2010, 20, 3, 218-224

[8] Documents of 2670 Staubli rotational dobby

[9] Cardozo, W.S., Weber, H.I., Dynamic modeling of a 2-dof parallel electrohydraulic-actuated homokinetic platform, In: Mechanism and Machine Theory, 2017, 118, 1-13 
[10] Yin, H.H., Yu, H.B., Jin, Y.L., et al., Comprehensive performance test of dobby and analysis system, In: Proceedings of the 2016 International Conference on Mechatronics Engineering and Information Technology (ICMEIT), 2016, 8, 343-348

[11] Can, O., Abdulla, G., Design of a new rotary dobby mechanism, In: Industria Textila, 2018, 69, 6, 429-433, http://doi.org/10.35530/IT.069.06.1484

[12] Zhang, R.I., Li, Z.X., Analysis of fabric tissue programmer for electronic dobby jacquard system, In: Advanced Textile Technology, 2000, 8, 1, 21-25

\author{
Authors: \\ HONGHUAN YIN ${ }^{1}$, HONGBIN YU ${ }^{1}$, JUNQIANG PENG ${ }^{1}$, HONGYU SHAO ${ }^{2}$ \\ ${ }^{1}$ Tianjin Polytechnic University, School of Mechanical Engineering, 300387, Tianjin, China \\ e-mail: yhh201184@163.com, yuhongbin@tjpu.edu.cn \\ ${ }^{2}$ Tianjin University, School of Mechanical Engineering, 300072, Tianjin, China \\ e-mail: shaohongyu@tju.edu.cn

\section{Corresponding author:} \\ JUNQIANG PENG \\ e-mail: pengjunqiang@tjpu.edu.cn
}

